\title{
INTERESTERIFIKASI MINYAK KELAPA SAWIT DENGAN METIL ASETAT UNTUK SINTESIS BIODIESEL MENGGUNAKAN CANDIDA RUGOSA LIPASE TERIMOBILISASI
}

\author{
Heri Hermansyah*, Septhian Marno, Rita Arbianti, \\ Tania Surya Utami, dan Anondho Wijanarko \\ Departemen Teknik Kimia, Fakultas Teknik, Universitas Indonesia \\ Kampus Baru UI Depok 16424 \\ Email: heri@chemeng.ui.ac.id
}

\begin{abstract}
Abstrak
Saat ini riset sintesis biodiesel menggunakan biokatalis sangat menjanjikan karena mampu memperbaiki kelemahan katalis alkali, yaitu kemudahan pemisahan produk dan kemampuan dalam mengarahkan reaksi secara spesifik tanpa adanya reaksi samping yang tidak diinginkan. Namun, biokatalis mudah terdeaktivasi dalam lingkungan beralkohol. Oleh karena itu, dalam riset ini diusulkan untuk melakukan sintesis biodiesel melalui rute non-alkohol untuk menjaga agar aktivitas dan stabilitas biokatalis tetap tinggi selama reaksi berlangsung. Dalam makalah ini akan disajikan hasil penelitian sintesis biodiesel rute non-alkohol menggunakan Candida rugosa lipase yang diimobilisasi dalam zeolit melalui metode adsorpsi dengan mereaksikan metil asetat sebagai penyuplai gugus alkil dengan trigliserida dari minyak kelapa sawit dalam reaktor batch. Hasil analisis HPLC menunjukkan bahwa lebih dari $82 \%$ rantai asam lemak dari trigliserida minyak kelapa sawit berhasil dikonversikan menjadi biodiesel pada kondisi konsentrasi biokatalis sebesar $4 \%$-wt substrat dan rasio mol minyak/alkil sebesar $1 / 12$ selama 50 jam reaksi. Pengaruh rasio reaktan, konsentrasi biokatalis terhadap profil konsentrasi dari tri-, di-, mono-gliserida serta biodiesel juga diselidiki. Uji stabilitas menunjukkan bahwa biokatalis terimobilisasi ini masih memiliki aktivitas untuk tiga kali siklus reaksi. Mekanisme Michaelis-Menten digunakan untuk menurunkan persamaan kinetika reaksi yang mampu menggambarkan perilaku produksi biodiesel yang dihasilkan.
\end{abstract}

Kata kunci: biodiesel, interesterifikasi, Candida rugosa lipase, rute non alkohol, imobilisasi

\begin{abstract}
Biocatalyst is a promising alternative catalyst for synthetic biodiesel because it has capability to improve conventional catalyst weakness, such as product purification and undesired side products. However, biocatalyst is easy to be deactivated by alcohol. Therefore, in this research, new method is developed to maintain the activity and stability of biocatalyst during reaction. In this paper, the experimental results of non-alcohol route synthesis of biodiesel using immobilized candida rugosa lipase in zeolit through adsorption method were reported. Methyl acetate as alkyl acceptor was reacted with triglyceride from palm oil in batch reactor. The analytical results from HPLC showed that trioleat convert up to $82 \%$ under the condition of $4 \%$-wt substrate of the biocatalyst concentration and oil/alkyl mole ratio equal to $1 / 12$ in 50 hour reaction. The effects of reactant ratio, biocatalyst concentration on concentration profile of tri-, di-, mono-gliceryde, and biodiesel were also observed. Stability test indicated that the activity of the immobilized biocatalyst still remained active for three reaction cycles. Michaelis-Menten mechanism was used for derivation kinetic reaction equation to describe the behaviour of biodiesel production.
\end{abstract}

Keywords: Biodiesel, interesterification, Candida rugosa lipase, non-alcohol route, immobilized.

*korespondensi 


\section{Pendahuluan}

Baru-baru ini biodiesel telah menarik perhatian sebagai sumber energi alternatif. Biodiesel (fatty acid methyl ester) telah diproduksi secara komersial melalui reaksi transesterifikasi minyak nabati dengan metanol menggunakan katalis alkali. Tetapi katalis alkali ini mempunyai beberapa kelemahan, seperti terjadinya reaksi pembentukan sabun akibat bereaksinya katalis (logam alkali) dengan asam lemak bebas. Selain itu, katalis yang bercampur homogen juga mengakibatkan kesulitan dalam pemurnian produk (Ma dan Milford, 1999). Proses pemurnian produk yang cukup sulit inilah yang pada akhirnya mengakibatkan harga biodiesel menjadi cukup mahal.

Akhir-akhir ini mulai dikembangkan sintesis biodiesel menggunakan enzim lipase sebagai biokatalis. Lipase sebagai biokatalis mampu mengarahkan reaksi secara spesifik ke arah produk yang diinginkan tanpa terjadinya reaksi samping yang merugikan. Biokatalis ini merupakan katalis heterogen, sehingga pemisahannya dari produk setelah reaksi berakhir dapat dilakukan dengan mudah. Namun, enzim lipase mudah terdeaktivasi oleh alkohol yang merupakan reaktan dalam proses enzimatik sintesis biodiesel ini. Oleh karena itu, perlu dikembangkan metode baru untuk meningkatkan aktivitas dan stabilitas lipase dalam proses sintesis biodiesel.

Metode baru yang akan dikembangkan adalah dengan mengubah rute reaksi dari menggunakan alkohol ke rute reaksi yang tidak menggunakan alkohol. Rute reaksi nonalkohol bisa dilakukan dengan cara mengganti alkohol dengan alkil asetat yang sama-sama berfungsi sebagai penyuplai alkil. Reaksi trigliserida dari minyak sawit dengan alkil asetat akan menghasilkan biodiesel (fatty acid alkil ester). Keberhasilan penelitian ini diharapkan dapat memberikan kontribusi pada peningkatan efisiensi sintesis biodiesel menggunakan lipase, sehingga sistem produksi biodiesel menggunakan katalis berbasis biokatalis bisa layak secara ekonomi untuk dikomersialkan di level industri. Dalam penelitian ini, untuk menyiasati mahalnya penggunaan biokatalis, maka biokatalis yang digunakan yaitu candida rugosa lipase yang diimmobilisasi dengan menggunakan metode adsorpsi

Shimada dkk. (1999) melakukan sintesis biodiesel menggunakan minyak sawit bekas dan Novozym 435 sebagai katalis melalui rute alkohol dengan metanol sebagai pendonor alkil (acyl acceptor) dan diperoleh konversi 90\%. Baru pada tahun 2004 riset sintesis biodiesel melalui rute non-alkohol ini dilakukan oleh grup riset dari China dengan hasil dua publikasi internasional (Du dkk., 2004). Pada tahun 2005, Xu dkk. melakukan studi perbandingan antara sintesis biodiesel melalui rute alkohol dan rute non-alkohol menggunakan substrat minyak kedelai dan Novozym 435 sebagai biokatalis. Diperoleh \%-yield metil ester mencapai 92\%. Riset dilanjutkan oleh Du dkk. pada tahun 2004 dengan melakukan pemodelan kinetika terhadap lipase dalam mengkatalis reaksi interesterfikasi sintesis biodiesel rute nonalkohol menggunakan pemodelan Ping Pong Bi Bi.

Dalam penelitian ini, reaksi sintesis biodiesel yang dilakukan adalah dari minyak sawit melalui rute non-alkohol menggunakan biokatalis lipase Candida rugosa powder yang diimobilisasi menggunakan metode adsorpsi. Penelitian ini berada pada tahap reaktor batch.

\section{Dasar Teori}

Pada umumnya, biodiesel diproduksi dengan mereaksikan minyak nabati dan alkohol beserta penggunaan katalis. Produk dari reaksi produksi biodiesel tersebut adalah campuran antara asam lemak alkil ester, yang dikenal dengan nama biodiesel, dan gliserol (Fukuda dkk., 2001). Prosesnya disebut dengan nama transeterifikasi atau alkoholisis seperti yang terlihat pada Gambar 1.

$\mathrm{R}_{1}, \mathrm{R}_{2}$, dan $\mathrm{R}_{3}$ merupakan asam lemak yang tergantung dari tipe minyak nabati. Rantainya bisa sama atau berlainan. Alkohol yang digunakan juga dapat berbeda. Jika metanol yang digunakan, maka akan dihasilkan asam lemak metil ester, sedangkan jika etanol yang digunakan, maka akan menghasilkan asam lemak etil ester. Karena harga metanol lebih murah, maka alkohol ini lebih sering digunakan dalam proses produksi biodiesel.

Ada beberapa pilihan katalis reaksi yang dapat digunakan. Selama ini, biodiesel komersial biasanya menggunakan proses dengan katalis alkali untuk proses transesterifikasi. Meskipun demikian, proses transesterifikasi dengan katalis alkali mempunyai beberapa kelemahan, diantaranya: 


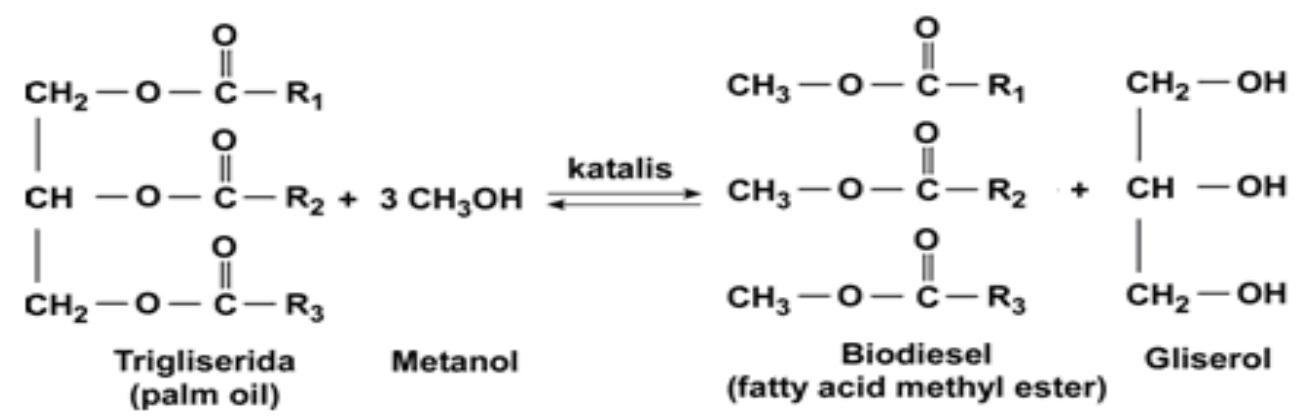

Gambar 1. Reaksi keseluruhan transesterifikasi trigliserida dari minyak nabati dengan alkohol

1. Katalis alkali dalam bentuk cair bercampur sempurna dengan produk sehingga pemurnian produk dari katalis relatif sulit.

2. Digunakannya katalis alkali juga mengakibatkan terjadinya reaksi samping yang sangat mengganggu yaitu terjadinya reaksi saponifikasi membentuk produk samping yang tidak diinginkan sehingga menurunkan yield biodiesel.

Kedua hal di atas mengakibatkan dibutuhkannya proses pemurnian produk lebih lanjut yang relatif sulit dan mahal.

Penggunaan katalis alkali menyisakan masalah dalam hal pemurnian produk sehingga diperlukan katalis heterogen dan mampu mengarahkan reaksi secara spesifik. Akhir-akhir ini, penelitian sintesis biodiesel menggunakan enzim lipase banyak dilakukan. Beberapa peneliti menggunakan lipase dari Candida sp., Pseudomonas sp. (Noureddini dkk, 2005) dan Rhizopus sp (Kaieda dkk., 1999).

Menurut Vincente (2004), enzim lipase sebagai katalis untuk produksi biodiesel sangat menjanjikan karena mampu memperbaiki kelemahan katalis alkali, yaitu :

1. Berbeda fasa dengan reaktan/produk baik dalam bentuk free atau terimobilisasi sehingga biokatalis dapat dipisahkan dari sistem dengan mudah.

2. Mampu mengarahkan reaksi secara specifik tanpa adanya reaksi samping yang tak diinginkan, seperti reaksi penyabunan.

\section{Interesterifikasi Metil Ester dari Rute Non Alkohol}

Meskipun penggunaan lipase memiliki banyak kelebihan, penggunaan lipase sebagai katalis untuk sintesis biodiesel juga masih menyisakan masalah yang cukup besar. Lingkungan beralkohol seperti metanol menyebabkan lipase terdeaktivasi secara cepat dan stabilitasnya dalam mengkatalisis reaksi menjadi buruk (Kaieda dkk., 2001). Akibatnya, biokatalis tersebut tidak bisa dipakai ulang. Hal ini mengakibatkan biaya produksi yang tinggi sehingga sintesis biodiesel menggunakan biokatalis belum bisa dilakukan secara komersial. Proses reaksinya dapat dilihat pada Gambar 2.

Dari uraian di atas, kita bisa mengetahui bahwa lipase mempunyai potensi besar sebagai katalis untuk sintesis biodiesel menggantikan katalis alkali. Tetapi, alkohol berantai pendek seperti metanol yang biasa digunakan sebagai penyuplai gugus alkil mempunyai pengaruh buruk bagi aktivitas dan stabilitas lipase. Untuk menyelesaikan masalah tersebut, dalam penelitian ini akan diusulkan rute baru untuk mensintesis biodiesel menggunakan rute non-alkohol.

Dalam sintesis biodiesel rute alkohol, alkohol (metanol) berfungsi untuk menyuplai gugus alkil (metil). Sementara itu, dalam sintesis biodiesel rute non-alkohol, metanol bisa digantikan dengan metil asetat sebagai penyuplai gugus metil seperti yang diperlihatkan dalam Gambar 2. Penggantian alkohol dengan alkil asetat ini diharapkan mampu meningkatkan stabilitas enzim lipase selama proses reaksi secara signifikan.

Di samping itu, produk samping rute non-alkohol ini yaitu triasetilgliserol mempunyai nilai jual yang lebih tinggi dibanding produk samping rute alkohol yaitu gliserol. Peningkatan stabilitas enzim dan produk samping yang bernilai lebih tinggi diharapkan mampu membuat sintesis enzimatik biodiesel bisa lebih kompetitif di level industri dan layak untuk dikomersialkan di masa depan.

Penggunaan enzim sebagai biokatalis mempunyai beberapa kelemahan, antara lain yaitu harga enzim yang sangat 
<smiles></smiles>

Trigliserida (palm oil)

Metil Asetat<smiles>[R]C(=O)OC</smiles>

Biodiesel

(fatty acid methyl ester)
Triacetylglyserol

\section{Gambar 2. Reaksi interesterifikasi minyak nabati melalui rute reaksi non alkohol}

mahal, ketidak-stabilan enzim, ketersediaan enzim yang sangat sedikit, dan mahalnya biaya untuk recovery enzim yang digunakan pada reaksi dalam media cair karena sifat enzim yang larut dalam media cair.

Imobilisasi enzim disini maksudnya adalah menggabungkan suatu enzim dengan suatu matriks padat (support) secara fisik, sehingga dapat digunakan secara berulang kali dan secara kontinyu. Teknik ini dikembangkan untuk memperbaiki beberapa kekurangan penggunaan enzim tersebut.

Teknik imobilisasi yang digunakan adalah dengan metode adsorpsi. Adsorpsi didasari pada kontak antara enzim dengan permukaan support, seperti yang ditunjukkan pada Gambar 3. Bergantung dari sifat alami permukaan tersebut, ikatan enzim boleh jadi hasil dari interaksi ionik, adsorpsi fisik, ikatan hidrofobik, gaya van der waals, atau kombinasi dari semuanya.

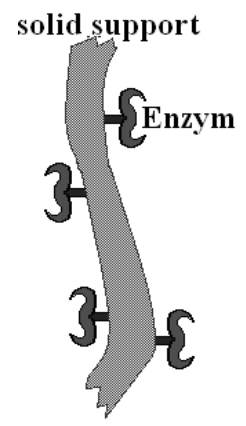

\section{Gambar 3. Enzim pada permukaan support}

\section{Pemodelan Reaksi}

Reaksi enzimatis sintesis biodiesel diasumsikan mengikuti mekanisme Michaelis-Menten sebagai berikut:

$E+S \underset{k_{2}}{\stackrel{k_{1}}{\rightleftarrows}} E S \stackrel{k_{p}}{\longrightarrow} E+P$
Notasi E dan S adalah enzim dan substrat, $\mathrm{P}$ merupakan produk, dan.notasi ES merupakan enzim-substrat kompleks.

Dalam hubungan dengan penelitian ini, karena substrat yang digunakan adalah trigliserida, maka notasi S diganti oleh notasi $\mathrm{T}$ yang artinya trigliserida. Produk yang terbentuk adalah biodiesel, maka notasi $\mathrm{P}$ diganti oleh notasi B yang artinya biodiesel. Sehingga reaksinya ditulis ulang sebagai berikut:

$E+T \underset{k_{2}}{\stackrel{k_{1}}{\rightleftarrows}} E T \stackrel{k_{p}}{\longrightarrow} E+B$

Keterangan: $\mathrm{E}=$ Enzim; $\mathrm{T}=$ Trigliserida; $\mathrm{ET}=$ enzim-substrat kompleks; dan B = Biodiesel.

Dengan menambahkan asumsi pseudosteady state, diperoleh persamaan laju produksi biodiesel sebagai berikut:

$$
\frac{d[B]}{d t}=\frac{V_{\max }[T]}{[T]+k_{m}}
$$

Notasi $\mathrm{k}_{\mathrm{m}}$ disebut sebagai konstanta Michaelis-Menten dan $\mathrm{V}_{\max }$ merupakan konstanta laju maksimal. Nilai $\mathrm{k}_{\mathrm{m}}$ dan $\mathrm{V}_{\text {max }}$ diperkirakan melalui metode linierisasi seperti berikut:

$$
\begin{aligned}
\frac{1}{\frac{d[B]}{d t}}= & \frac{1}{V_{\max }}+\frac{k_{m}}{V_{\max }}\left(\frac{1}{[T]}\right) \\
\downarrow & \downarrow \quad \downarrow \quad \downarrow \quad \\
y \quad= & a+b \quad x \quad \text { (4) } \\
\text { Sebagai sumbu } & \text { y adalah } \quad y=1 /\left(\frac{d[B]}{d t}\right)
\end{aligned}
$$
sedangkan sebagai sumbu $\mathrm{x}$ adalah $\mathrm{x}=1 / \mathrm{T}$ sehingga jika diplot nilainya akan 
menghasilkan slope $\mathrm{b}=\mathrm{k}_{\mathrm{m}} / \mathrm{V}_{\max }$ dan intersep $\mathrm{a}=1 / \mathrm{V}_{\text {max }}$.

\section{Metodologi}

Bahan Percobaan yang digunakan dalam penelitian ini adalah enzim lipase (Candida rugosa lipase), minyak kelapa sawit Indonesia yang berasal dari pasar lokal dalam negeri, zeolit lampung yang digunakan sebagai material penyangga untuk mengimobilisasi biokatalis, dan metil asetat.

Tahap percobaan yang pertama kali dilakukan adalah mempersiapkan zeolit yang sudah teraktivasi untuk kemudian dimasukkan ke dalam larutan metil asetat yang sudah berisi lipase. Zeolit kemudian diaduk pada temperatur ruang. Diharapkan selama proses pengadukan terjadi proses adsorpsi dimana terjadi pertukaran ionionnya antara lipase dan zeolit. Pada tahap proses adsorpsi inilah lipase akan menempel pada penyangganya (lipase terimobilisasi). Larutan lipase diimobilisasi selama 60 menit. Butiran penyangga kemudian dipisahkan dari sisa larutan lipase menggunakan molekular sieve.

Seperti yang terlihat pada Gambar 4, reaksi akan dilangsungkan dalam reaktor batch (labu erlenmeyer $25 \mathrm{ml}$ ) yang berisi campuran minyak kelapa sawit dan metil asetat dengan perbandingan mol yang berbeda-beda. Immobilized lipase yang digunakan adalah 1\%, 2\%, dan 4\%-wt dari substrat campuran minyak sawit dan metil asetat. Percobaan uji aktivitas akan dilakukan juga, yaitu variasi mol substrat dengan perbandingan mol minyak sawit terhadap metil setat adalah 1:3 dan 1:12.

Untuk variasi waktu, proses pengambilan sampel dilakukan pada t (jam):
$0,0,25,0.5,1,2,4,6,9,12,15,20,25,30,35$, 40, 45, dan 50 .

Konsentrasi dari biodiesel yang terbentuk diukur menggunakan HPLC (Hitachi, UV $205 \mathrm{~nm}$, kolom C18 reverse phase 4,6x150 mm). Optimasi kondisi operasi untuk reaksi sintesis biodiesel menggunakan lipase yang sudah diimobilisasi dilangsungkan dengan melakukan variasi konsentrasi enzim. Data mentah yang didapat dari kedua alat tersebut kemudian diolah menggunakan MS. Excel untuk mendapatkan data-data yang dibutuhkan dan diekspresikan baik dalam bentuk tabel ataupun gambar.

\section{Uji Stabilitas}

Uji stabilitas juga dilakukan dengan menggunakan biokatalis yang diimobilisasi menggunakan metode adsorpsi. Reaksi dilangsungkan dalam reaktor batch yang berisi campuran minyak kelapa sawit dan metil asetat menggunakan konsentrasi enzim 4\%-wt substrat, dengan perbandingan mol substrat minyak sawit : metil asetat adalah 1:12. Uji stabilitas dilangsungkan pada suhu $37{ }^{\circ} \mathrm{C}$ dan dilakukan secara berulang sebanyak 2 kali. Sampel minyak sebanyak 1 $\mu \mathrm{L}$ dipisahkan dari larutan reaksi kemudian dianalisis menggunakan HPLC untuk mengukur konsentrasi biodiesel yang terbentuk. Setelah reaksi selesai, biokatalis tersebut kemudian disaring dan dipisahkan dari larutannya dan dikeringkan pada temperatur kamar dalam desikator. Reaksi kemudian diulang sebanyak dua kali dengan prosedur yang sama menggunakan biokatalis bekas tersebut. Dari tahapan percobaan ini akan diketahui stabilitas biokatalis dalam melakukan sintesis biodiesel melalui rute non -alkohol.

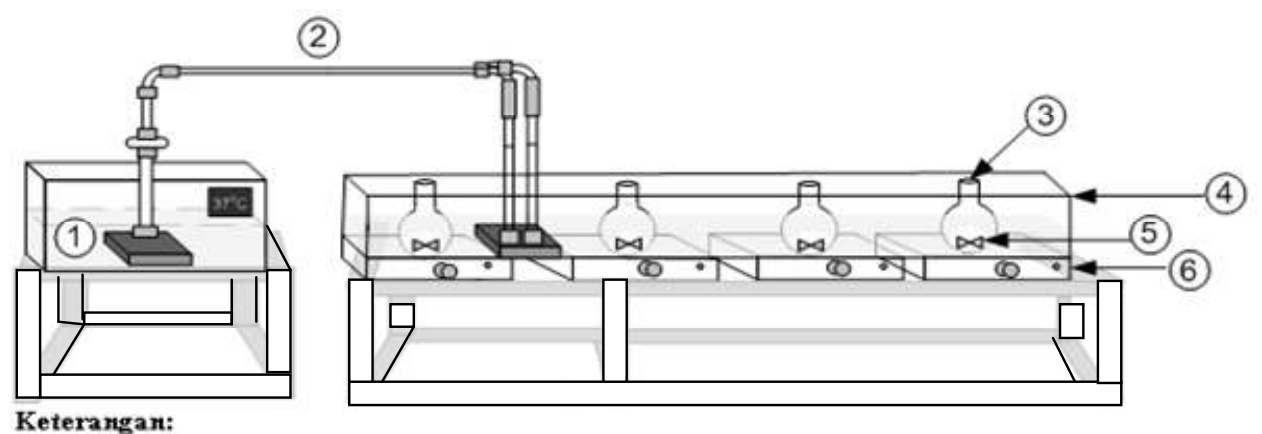

1. Water bath; 2. Rangkaian pompa air ; 3. Erlenmeyer $25 \mathrm{ml}$;

4. Wadah air (tupper wane); 5. Bar stirrer; 6. Magnetic stirer

\section{Gambar 4. Skematik reaktor batch interesterifikasi sintesis biodiesel secara enzimatik}




\section{Pemodelan Reaksi Enzimatik Michaelis-} Menten

Untuk reaksi enzimatis pembentukan produk biodiesel, model kinetikanya dapat dirumuskan berdasarkan mekanisme reaksi enzimatis berbasis mekanisme MichaelisMenten. Pada penelitian ini, pemodelan dan kurva fitting dilakukan dalam beberapa langkah yaitu langkah petama mempersiapkan data hasil interesterifikasi sintesis biodiesel selama penelitian, kemudian melakukan penurunan rumus secara aljabar dari persamaan reaksi enzimatik Michaelis-Menten. Setelah didapatkan penurunan rumusnya, langkah selanjutnya adalah melakukan fitting kurva dengan metode linierisasi. Pada proses fitting kurva, harus dilakukan penyesuaian antara data-data hasil percobaan dengan model reaksi Michaelis-Menten menggunakan metode linierisasi yang diturunkan persamaannya agar kemudian didapatkan nilai $\mathrm{V}_{\max }$ dan $\mathrm{k}_{\mathrm{m}}$ yang belum diketahui pada persamaan model reaksi. Kemudian langkah terakhirnya adalah membahas hasil permodelan.

\section{Hasil dan Pembahasan}

Berikut adalah hasil sintesis biodiesel menggunakan biokatalis candida rugosa lipase yang diimobilisasi dengan metode adsorpsi. Dalam penelitian ini, reaksi yang dilakukan berlangsung melalui rute nonalkohol, yaitu minyak sawit direaksikan dengan metil asetat sebagai penyuplai gugus alkil dalam reaksi interesterifikasi.

Gambar 5 memperlihatkan bahwa konsentrasi biodiesel yang tebentuk mempunyai trend yang terus meningkat seiring bertambahnya konsentrasi biokatalis. Hal ini disebabkan kecepatan reaksi enzimatik tergantung pada konsentrasi enzim yang berperan sebagai katalisator di dalam reaksi. Dengan kata lain, konsentrasi enzim dan substrat mempengaruhi laju pembentukan produk. Dari Gambar 5 terlihat adanya pengaruh penambahan substrat dan konsentrasi biokatalis terhadap meningkatnya poduk yang dihasilkan. Hal ini terlihat dari konsentrasi biodiesel yang terbentuk terbesar, yaitu 3,98 mol/L.

Dari tahapan ini terlihat bahwa peningkatan konsentrasi enzim secara umum berhasil meningkatkan konsentrasi biodiesel yang terbentuk. Hasil ini sesuai dengan prinsip reaksi enzimatis pada umumnya, yaitu adanya pengaruh konsentrasi enzim (biokatalis) terhadap meningkatnya laju awal reaksi dalam pembentukan produk.

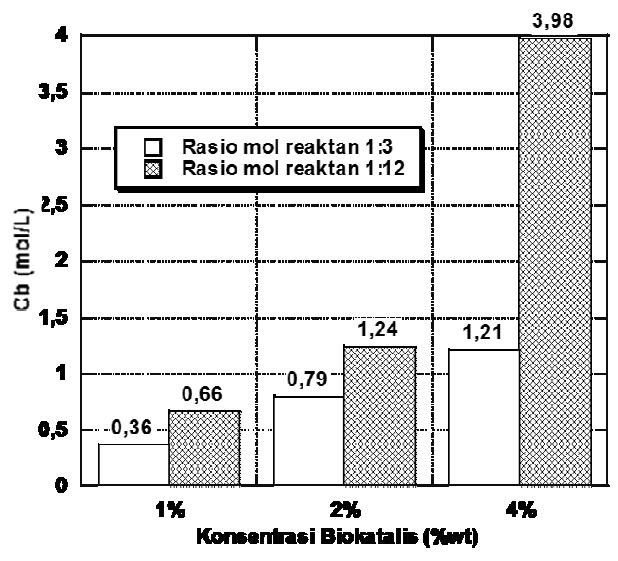

Gambar 5. Pengaruh konsentrasi biokatalis terhadap biodiesel yang dihasilkan pada perbedaan rasio reaktan menggunakan lipase terimobilisasi metode adsorpsi (substrat: minyak sawit; $\mathrm{t}=50 \mathrm{jam} ; \mathrm{T}=37^{\circ} \mathrm{C}$ )

Untuk mengetahui laju pembentukan masing-masing komponen terhadap waktu, maka dalam penelitian ini dilakukan variasi waktu. Banyaknya jumlah konsentrasi biodiesel yang terbentuk dalam waktu tertentu dapat menunjukkan kinerja optimal dari enzim sebagai biokatalis.

Berdasar Gambar 6, mengenai profil laju reaksi konsentrasi trioleat (mol/L) yang terbentuk, maka didapatkan trend profil kosentrasi yang terus menurun. Penurunan konsentrasi trioleat menunjukkan adanya laju reaksi pembentukan produk selama reaksi. Hal ini terlihat dari pofil konsentrasi biodiesel yang terus meningkat seiring meningkatnya waktu. Berdasarkan persamaan laju reaksi, dengan semakin lamanya waktu reaksi maka produk yang dihasilkan akan semakin besar. Dari kurva laju pembentukan biodiesel, terlihat bahwa konsentrasi terbesar terbentuk saat $t=50$ jam dengan nilai 3,98 mol/L dan nilai konversi trioleat yang dicapai adalah lebih dari $82 \%$

Nilai konversi ini belum terlalu optimal jika dibandingkan dengan sintesis biodiesel rute konvensional yang biasanya konversimya mencapai lebih dari 90\%. Hal ini disebabkan oleh adanya sebagian free lipase yang tidak terikat secara sempurna pada zeolit. Selain itu, pengaruh luas kontak biokatalis di permukaan zeolit untuk 
mengikat substrat juga menjadi salah satu faktor penyebab lebih rendahnya konsentrasi biodiesel yang terbentuk dari imobilisasi metode adsorpsi.

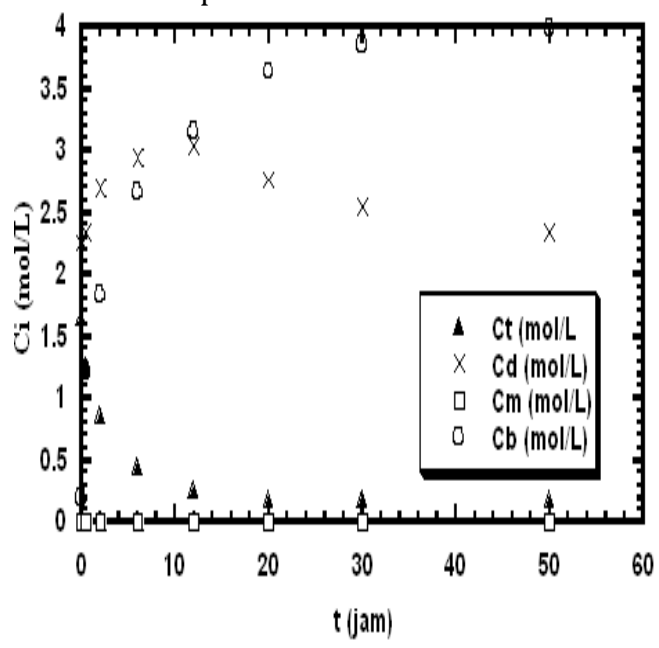

Gambar 6. Laju konsentrasi semua komponen (mol/L) dalam reaksi interesterifikasi sintesis biodiesel menggunakan lipase terimobilisasi metode adsorpsi. (Substrat: minyak sawit; $\mathrm{t}=50 \mathrm{jam} ; \mathrm{T}=37^{\circ} \mathrm{C}$ )

Bagian berikutnya adalah melakukan uji stabilitas terhadap lipase yang terimobilisasi dengan metode adsorpsi. Uji stabilitas yang dimaksud dalam bagian ini adalah penggunaan enzim secara berulang dari reaksi sebelumnya. Hal ini dilakukan untuk mengetahui kestabilan lipase terimobilisasi metode adsorpsi sebagai biokatalis dalam memproduksi biodiesel. Selain itu, uji stabilitas juga dilakukan untuk melihat kemampuan metode adsorpsi dalam mengikat enzim.

Gambar 7 memperlihatkan bahwa konsentrasi biodiesel yang terbentuk mengalami penurunan setelah di-recycle untuk kedua dan ketiga kalinya. Penurunan konsentrasi biodiesel ini disebabkan oleh daya ikat support dalam mengikat enzim yang semakin melemah. Hal ini mengakibatkan ketidak-stabilan pada lipase dalam mengkatalisis reaksi. Indikasi lain yang terjadi adalah berkurangnya aktifitas enzim akibat sudah jenuhnya enzim dalam mengikat substrat sehingga daerah aktif enzim berkurang.

Penggunaan lipase yang pertama kali dapat menghasilkan konsentrasi biodiesel sebesar 3,98 mol/L. Namun, terjadi

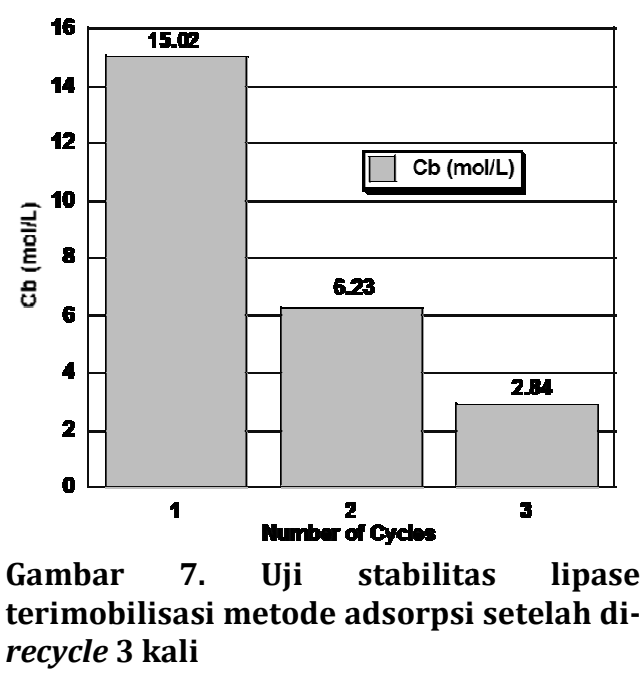

penurunan konsentrasi biodiesel yang cukup signifikan setelah lipase di-recycle untuk kedua kalinya. Nilai konsentrasinya menjadi 1,26 mol/L, kemudian kembali turun saat direcycle untuk ketiga kalinya, yaitu menjadi 0,87 mol/L. Penurunan konsentrasi biodiesel bisa disebabkan oleh larutnya zeolit ketika akan digunakan untuk kedua dan ketiga kalinya. Penurunan aktivitas enzim juga dilaporkan oleh Mamoru iso et.al. yang menggunakan teknik imobilisasi metode adsorpsi. Dalam laporannya, enzim mengalami penurunan aktivitas sebanyak 2/3 dari aktivitas awalnya selama 1 jam. Penurunan aktivitas ini dilihat dari semakin turunnya konversi propil-oleat setelah 1 jam. Setelah 1 kali diulang, \%-konversi ke propiloleat hanya mencapai $80 \%$ dari awalnya yang mencapai $95 \%$.

\section{Hasil Pemodelan dan Reaksi Michaelis- Menten}

Dari hasil pemodelan reaksi enzimatik menggunakan mekanisme reaksi MichaelisMenten, didapat nilai $\mathrm{V}_{\max }$ dan $\mathrm{k}_{\mathrm{m}}$ dari reaksi sintesis biodiesel menggunakan Candida rugosa terimobilisasi metode adsorpsi dengan nilai $\mathrm{V}_{\max }=-0,089$ dan $\mathrm{k}_{\mathrm{m}}=-1,77$.

Pada Gambar 8 terlihat ada sedikit fenomena menarik disini ketika ditemukannya nilai persamaan garis dengan intersep negatif untuk pemodelan reaksi enzimatis Michaelis-Menten dari sintesis biodiesel menggunakan lipase terimobilisasi metode adsorpsi. Hal ini akan memberikan nilai $\mathrm{V}_{\max }$ dan $\mathrm{k}_{\mathrm{m}}$ yang negatif. Hal ini bisa dikarenakan oleh adanya kecepatan reaksi 
yang turun di selang waktu tertentu. Data reaksi enzimatis yang diperoleh cenderung berbentuk liner dengan mengikuti persamaan reaksi orde 1 . Selain itu, jumlah data yang digunakan untuk fitting kurva tidak mengambil nilai titik yang banyak. Titik yang digunakan pada umumnya hanya 5-8 titik untuk dilakukan linierisasi menggunakan mekanisme reaki enzimatis Michaelis-Menten. Kelemahan dari metode linierisasi ini adalah mekanisme raeaksi enzimatis oleh Michaelis-Menten terlalu sederhana untuk menjelaskan reaksi enzimatis pada proses reaksi pembentukan biodiesel yang berlangsung secara bertahap dan pada umumnya menghasilkan produk samping. Selain itu, ada faktor inhibisi yang tidak digunakan dalam mekanisme reaksi Michaelis-Menten tersebut.

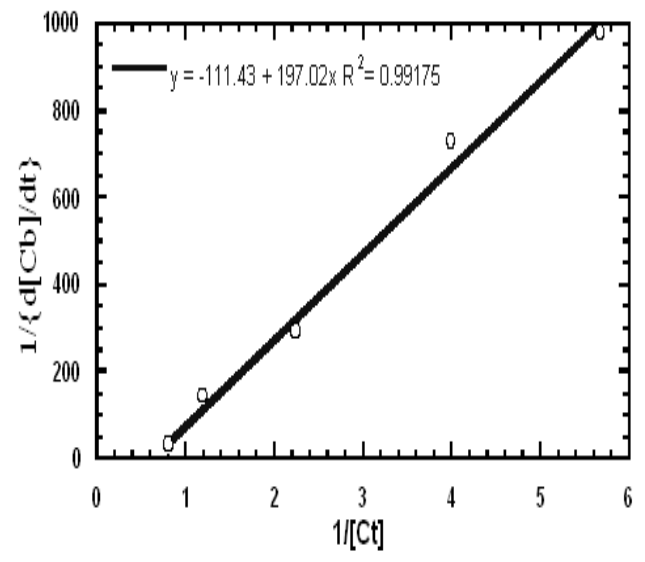

Gambar 8. Hasil pemodelan metode linierisasi terhadap hasil sintesis biodiesel menggunakan lipase terimobilisasi metode adsorpsi (substrat: minyak sawit; $\mathbf{t}=\mathbf{5 0}$ jam; $\mathbf{T}=37^{\circ} \mathrm{C}$; Rasio mol reaktan $=1: 12$ )

\section{Kesimpulan}

Dari hasil penelitian yang telah dilakukan, diperoleh kesimpulan sebagai berikut:

Penelitian ini memberikan hasil konsentrasi biodiesel tertinggi dalam penelitian ini yaitu sebesar 3,98 mol/L dengan konversi trioleat yang dihasilkan sebesar $82 \%$. Disini juga terlihat bahwa semakin lama waktu reaksi maka laju pembentukan ke arah produk yang dihasilkan akan semakin besar. Selama reaksi juga tidak terbentuk reaksi penyabunan selama reaksi menggunakan biokatalis.
Dalam penelitian ini didapatkan pula fakta bahwa kinerja biokatalis terdeaktivasi akibat penggunaan secara berulang. Pengurangan aktivitas lipase yang terjadi disebabkan oleh semakin lemahnya support dalam mengikat biokatalis yang menyebabkan ketidakstabilan pada biokatalis. Dalam hal pengaruh variasi konsentrasi enzim dan biokatalis, terlihat bahwa peningkatan jumlah konsentrasi biokatalis berpengaruh terhadap peningkatan konsentrasi biodiesel yang dihasilkan. Semakin besar jumlah biokatalis yang digunakan, maka produk (biodiesel) yang dihasilkan akan semakin besar

Dari hasil pemodelan yang dilakukan, maka model kinetika berbasis Michelismenten dinilai cukup untuk menggambarkan perilaku konsentrasi biodiesel, yang ditandai dengan didapatnya hasil fitting yang cukup baik untuk data konsentrasi biodiesel.

\section{Daftar Notasi dan Simbol}

$\begin{array}{ll}\mathrm{mg} / \mathrm{L} & \text { miligram/Liter } \\ \mathrm{gr} / \mathrm{mL} & \text { gram/Liter } \\ \mathrm{mol} / \mathrm{L} & \text { Mol/Liter } \\ \mathrm{T}\left({ }^{\circ} \mathrm{C}\right) & \text { Suhu }\left({ }^{\circ} \mathrm{C}\right) \\ \mathrm{t}(\mathrm{jam}) & \text { Waktu (jam) } \\ \mathrm{t}(\text { detik}) & \text { Waktu (detik) } \\ \mathrm{Ct} & \text { Konsentrasi trioleat } \\ \mathrm{Cd} & \text { Konsentrasi dioleat } \\ \mathrm{Cm} & \text { Konsentrasi monooleat } \\ \mathrm{Cb} & \text { Konsentrasi biodiesel } \\ & \text { (Methyl-oleat) } \\ \mathrm{wt} & \text { (weight) }\end{array}$

\section{Daftar Pustaka}

Ma, F.; Milford A. H., Biodiesel production: $a$ review, Bioresource Technology, 1999, Vol. 70(1), 1-15.

Shimada, Y.; Watanabe, Y.; Samukawa, T.; Sugihara, A.; Noda, H.; Fukuda, H.; Tominaga, Y., Conversion of Vegetable Oil to Biodiesel Using Immobilized Candida Antarctica Lipase, Journal of the American Oil Chemists' Society, 1999, Vol. 76(7), 789-793.

$\mathrm{Xu}$, Y.; Du, W.; Liu, D., Study on the kinetics of enzymatic interesterification of triglycerides for biodiesel production with methyl acetate as the acyl acceptor, Journal of Molecular Catalysis B: Enzymatic, 2005, Vol. 32(5-6), 241-245. 
Du, W.; Xu, Y.; Liu, D.; Zeng, J., Comparative study on lipase-catalyzed transformation of soybean oil for biodiesel production with different acyl acceptors, Journal of Molecular Catalysis B: Enzymatic, 2004, Vol. 30(3-4), 125-129.

Fukuda, H.; Kondo, A.; Noda, H., Biodiesel fuel production by transesterification of oils, Journal of Bioscience and Bioengineering, 2001, Vol. 92(5), 405-416.

Noureddini, H.; Gao, X.; Philkana, R.S., Immobilized Pseudomonas cepacia lipase for biodiesel fuel production from soybean oil. Bioresource Technology, 2005, Vol. 96(7), 769-777.
Kaieda, M.; Samukawa, T.; Matsumoto, T.; Ban,K.; Kondo, A.; Shimada, Y.; Noda, H.; Nomoto, F.; Ohtuka, K.; Izumoto, E.; Fukuda, H., Biodiesel fuel production from plant oil catalyzed by Rhizopus oryzae lipase in a water-containing system without an organic solvent. Journal of Bioscience and Bioengineering, 1999, Vol. 88(6), 627-631.

Kaieda, M.; Samukawa, T.; Kondo, A.; Fukuda, $\mathrm{H} .$, Effect of methanol and water contents on production of biodiesel fuel from plant oil catalyzed by various lipases in a solvent-free system". Journal of Bioscience and Bioengineering, 2001, Vol. 91(1), 12-15. 